\title{
Studi Komparatif (Comparative Constitutional Law) Antara Negara Demokrasi dan Negara Islam di Tinjau dari Persfektif Politik dan Keadilan
}

\author{
Afrinald Rizhan \\ Program Studi Ilmu Hukum Fakultas Ilmu Sosial \\ Universitas Islam Kuantan Singingi, Riau Indonesia \\ afrinaldrizhan@gmail.com
}

\begin{abstract}
The law is always identified with justice, because the law must reflect justice and at the same time maintain justice. Law as a moral category is similar to justice. The word "justice" is of course also used in the legal sense, in terms of compatibility with positive law, especially in conformity with the Act. The only thing that is always demanded by the community is justice, not the law. Because justice is an irrational ideal, and justice is not the goal of knowledge, so what is learned in science is law, even though justice itself is indispensable to human will and action. Justice is something that is difficult to reach. Seeing the number of elements that affect or the parties related to justice itself. Justice that tends to be relatively large influenced by political elements. Legal politics is a legal policy or legal (policy) line of law that will be enforced either by the creation of a new law or by the replacement of the old law, in order to achieve the objectives of the State. In other words Political law is a series of concepts and principles that outline and basic plan in the implementation of a job, leadership, and how to act in the field of law. The purpose of this study is to determine the comparison between the State of Democracy and Islamic State when viewed from Politics and Justice. Type of research conducted is normative legal research, namely research conducted on legal principles and legal synchronization level. The analysis conducted in this research is qualitative analysis by drawing deductive conclusions that is drawing conclusions from things that are general to things that are special. The result of this research is Democracy State and Islamic State both using politics. Because, in simple terms politics is a strategy, a technique of governing. Politics has also been used in Islam since the time of Prophet Muhammad SAW. He as a person who spread the religion of Islam and in the spread of religion is using the same strategy as with politics. Justice is a thing that has always been the basis of the ideals of each State, whatever form the State certainly has a vision and mission that did not escape the desire of achieving justice. So also with the State of Democracy and Islamic State. In addition to the equality of vision and mission of justice, another apparent equation concerns the thought of the political system of the relationship between the people and the rulers and the responsibilities of government.
\end{abstract}

Keywords: state, politics, justice, democracy

\begin{abstract}
Abstrak
Hukum selalu diidentikkan dengan keadilan, karena hukum harus mencerminkan keadilan dan sekaligus dapat menjaga keadilan. Hukum sebagai kategori moral serupa dengan keadilan. Kata "keadilan" tentu saja juga digunakan dalam pengertian hukum, dari segi kecocokan dengan hukum positif, terutama kecocokan dengan Undang-Undang. Hanya saja yang selalu dituntut oleh masyarakat adalah keadilan, bukan hukum. Karena keadilan adalah suatu cita-cita yang irasional, dan keadilan bukan sasaran dari pengetahuan, maka yang dipelajari dalam suatu ilmu pengetahuan adalah hukum, meskipun keadilan itu sendiri sangat diperlukan bagi kemauan dan tindakan manusia. Keadilan adalah sesuatu hal yang sulit di gapai. Melihat banyaknya unsur-unsur yang mempengaruhi atau pihak-pihak yang terkait dengan keadilan itu sendiri. Keadilan yang cenderung bersifat relatif banyak di pengaruhi oleh unsur-unsur politik. Politik hukum adalah legal policy atau garis (kebijakan) resmi tentang hukum yang akan diberlakukan baik dengan pembuatan hukum baru maupun dengan penggantian hukum lama, dalam rangka mencapai tujuan Negara. Dengan kata lain Politik hukum adalah rangkaian konsep dan asas yang menjadi garis besar dan dasar rencana dalam pelaksanaan suatu pekerjaan, kepemimpinan, dan cara bertindak dalam bidang hukum. Tujuan penelitian ini adalah untuk mengetahui perbandingan antara Negara Demokrasi dan Negara Islam apabila di tinjau dari Politik dan Keadilan. Jenis
\end{abstract}


Penelitian yang dilakukan adalah penelitian hukum normatif, yaitu penelitian yang dilakukan terhadap asas-asas hukum dan taraf sinkronisasi hukum. Analisis yang dilakukan dalam penelitian ini adalah analisis kualitatif dengan menarik kesimpulan secara deduktif yaitu menarik kesimpulan dari hal-hal yang bersifat umum kepada hal-hal yang bersifat khusus. Hasil yang didapat dari penelitian ini adalah Negara Demokrasi maupun Negara Islam sama-sama menggunakan politik. Karena, dalam permaknaan yang sederhana politik adalah strategi, teknik mengatur. Politik juga sudah digunakan dalam islam sejak zaman Nabi Muhammad SAW. Beliau selaku orang yang menyebarkan agama islam dan dalam penyebaran agama tersebut menggunakan strategi yang sama halnya dengan politik. Keadilan adalah suatu hal yang selalu menjadi dasar cita-cita setiap Negara, apapun bentuk Negara tersebut tentu mempunyai visi dan misi yang tak luput dari keinginan pencapaian keadilan. Begitu juga dengan Negara Demokrasi maupun Negara Islam. Selain persamaan terhadap visi dan misi keadilan tersebut, persamaan lain yang tampak adalah menyangkut pemikiran sistem politik tentang hubungan antara umat dan penguasa serta tanggung jawab pemerintahan.

Kata Kunci: negara, politik, keadilan, demokrasi

\section{PENDAHULUAN}

Hukum adalah sebuah entitas yang sangat kompleks, meliputi kenyataan kemasyarakatan yang majemuk, mempunyai banyak aspek, dimensi, dan fase. ${ }^{1}$ Ilmu hukum mempunyai jangkauan universal, melampaui batas-batas hukum suatu bangsa dan Negara tertentu. Ilmu hukum mempunyai hakikat interdisipliner. Hakikat ini kita ketahui dari digunakannya berbagai disiplin ilmu pengetahuan untuk membantu menerangkan berbagai aspek yang berhubungan dengan kehadiran hukum di masyarakat. Berbagai aspek dari hukum yang ingin kita ketahui ternyata tidak dapat dijelaskan dengan baik tanpa memanfaatkan disiplin-disiplin ilmu pengetahuan, seperti politik, antropologi, ekonomi dan lain-lainnya. ${ }^{2}$

Hukum selalu diidentikkan dengan keadilan, karena hukum harus mencerminkan keadilan dan sekaligus dapat menjaga keadilan. Hukum sebagai kategori moral serupa dengan keadilan. Kata "keadilan" tentu saja juga digunakan dalam pengertian hukum, dari segi kecocokan dengan hukum positif, terutama kecocokan dengan Undang-Undang. ${ }^{3}$ Hanya saja yang selalu dituntut oleh masyarakat adalah keadilan, bukan hukum. Karena keadilan adalah suatu cita-cita yang irasional, dan keadilan bukan sasaran dari pengetahuan, maka yang dipelajari dalam suatu ilmu pengetahuan adalah hukum, meskipun keadilan itu sendiri sangat diperlukan bagi kemauan dan tindakan manusia.

Hukum adalah kristalisasi atau formalisasi dari kaidah-kaidah atau norma lainnya di dalam masyarakat yang kemudian mempunyai sifat sendiri yakni bersifat memaksa dan dapat

\footnotetext{
${ }^{1}$ Hukum berakar dan terbentuk dalam proses interaksi berbagai aspek kemasyarakatan (politik, ekonomi, sosial, budaya, teknologi, keagamaan, dan sebagainya), dibentuk dan ikut membentuk tatanan masyarakat, bentuknya ditentukan oleh masyarakat dengan berbagai sifatnya, namun sekaligus ikut menentukan sifat masyarakat itu sendiri. Bernard Arief Sidharta, Refleksi tentang Struktur Ilmu Hukum: Sebuah Penelitian tentang Fondasi Kefilasafatan dan Sifat Keilmuan Ilmu Hukum sebagai Landasan Pengembangan Ilmu Hukum Nasional Indonesia, (Bandung: Mandar Maju, 1999), Hal. 116, Dalam Imam Syaukani dan Ahsin Thohari, Dasar-Dasar Politik Hukum, Raja Grafindo Persada, Jakarta: 2008, Hal. 1

${ }^{2}$ Satjipto Rahardjo, Ilmu Hukum, Citra Aditya Bakti, Bandung: 2000, Hal. 7

${ }^{3}$ Hans Kelsen, Pengantar Teori Hukum, Nusa Media, Bandung, 2009, Hal. 48
} 
dipaksakan dengan kekuatan penegak hukum. Salah satu masalah yang sekarang timbul adalah terlepasnya sukma hukum yakni keadilan dari banyak proses penegakan hukum karena hukum kemudian lebih banyak dihayati sebagai persoalan teknis-prosedural semata. Akibatnya, hukum kemudian menjadi alat permainan untuk mencari kemenangan di dalam sengketa atau berpekara di pengadilan dan bukan untuk menegakkan keadilan, kebenaran, dan ketertiban di dalam masyarakat. Penegakan hukum kemudian bermain atau terjebak di dalam permainan norma-norma tanpa mempedulikan manusianya sebagai subjek yang harus dilayani dengan hukum yang bersukmakan keadilan serta berlandaskan etika dan moral. ${ }^{4}$

Keadilan adalah sesuatu hal yang sulit di gapai. Melihat banyaknya unsur-unsur yang mempengaruhi atau pihak-pihak yang terkait dengan keadilan itu sendiri. Keadilan yang cenderung bersifat relatif banyak di pengaruhi oleh unsur-unsur politik. Politik hukum adalah legal policy atau garis (kebijakan) resmi tentang hukum yang akan diberlakukan baik dengan pembuatan hukum baru maupun dengan penggantian hukum lama, dalam rangka mencapai tujuan Negara. ${ }^{5}$ Dengan kata lain Politik hukum adalah rangkaian konsep dan asas yang menjadi garis besar dan dasar rencana dalam pelaksanaan suatu pekerjaan, kepemimpinan, dan cara bertindak dalam bidang hukum. ${ }^{6}$

Selain terlepasnya keadilan sebagai sukma hukum yang bersumber dari etika dan moral, masalah lain yang kita hadapi adalah hubungan antara hukum dan politik sebagai dua subsistem kemasyarakatan. Dalam hal-hal penting tertentu hukum lebih banyak didominasi oleh politik sehingga sejalan dengan melemahnya dasar etik dan moral, pembuatan dan penegakan hukum banyak diwarnai oleh kepentingan-kepentingan politik.

Adanya bermacam-macam bentuk negara tentu akan menimbulkan perbedaanperbedaan dalam berbagai konsep dan penerapan hukum di masing-masing negara tersebut. Antara hukum yang ada di negara demokrasi akan berbeda dengan hukum yang ada di negara islam. Hanya saja persamaan dari kedua negara tersebut adalah sama-sama menginginkan tercapainya keadilan. Akan tetapi proses pencapaian keadilan itu berbeda melihat adanya perbedaan konsep yang di terapkan di masing-masing negara serta seiring dengan perkembangan politik yang cenderung mempengaruhi pertumbuhan hukum dan keadilan.

Begitulah rangkaian pemaparan yang dapat penulis sampaikan mengenai konsep keadilan yang selalu diiming-imingi oleh politik. Itulah sebabnya untuk menjaga keadilan sosial dibutuhkan aturan hukum agar tidak selalu dimainkan oleh politik. Maka dari itu,

\footnotetext{
${ }^{4}$ Mahfud, Konstitusi dan Hukum dalam Kontroversi Isu, Rajawali Pers, Jakarta: 2009, Hal. 68-69

${ }^{5}$ Mahfud, Politik Hukum di Indonesia, Rajawali Pers, Jakarta: 2009, Hal. 1

${ }^{6}$ Imam Syaukani dan Ahsin Thohari, Dasar-Dasar Politik Hukum, Rajawali Pers, Jakarta: 2008, Hal. 22
} 
penulis ingin melakukan suatu perbandingan antara politik dan keadilan yang terjadi di Negara Demokrasi dengan Negara Islam. Sehingga penulis memberikan judul pada makalah ini yaitu " studi komparatif (comparative constitutional law) antara negara demokrasi dan negara islam di tinjau persfektif politik dan keadilan"

Tujuan penelitian ini adalah untuk mengetahui perbandingan antara negara demokrasi dan negara Islam ditinjau dari segi politik dan keadilan. Berdasarkan uraian latar belakang masalah tersebut, maka penulis merumuskan permasalahannya sebagai berikut :

Bagaimanakah perbandingan antara Negara Demokrasi dan Negara Islam apabila di tinjau dari Politik dan Keadilan?

\section{METODE PENELITIAN}

Jenis penelitian/ pendekatan yang digunakan oleh penulis adalah penelitian hukum normatif yaitu penelitian hukum kepustakaan, karena menjadikan bahan kepustakaan sebagai tumpuan utama. Dalam penelitian hukum normatif ini penulis melakukan penelitian terhadap asas-asas hukum yang bertitik tolak dari bidang-bidang tata hukum tertentu, dengan cara mengadakan identifikasi terlebih dahulu terhadap kaidah-kaidah hukum yang telah dirumuskan di dalam perundang-undangan tertentu.

Sebagai pendukung, penelitian ini juga menggunakan pendakatan empiris yaitu mendapatkan informasi yang akurat dengan cara mengadakan identifikasi hukum dan bagaimana efektifitas hukum itu berlaku dalam masyarakat.

Dalam konsep normatif, hukum adalah norma, baik yang diidentikkan dengan keadilan yang harus diwujudkan (ius constituendum) ataupun norma yang telah terwujud sebagai perintah yang eksplisit dan yang secara positif telah terumus jelas (ius constitutum) untuk menjamin kepastiannya, dan juga berupa norma-norma yang merupakan produk dari seorang hakim (judgements) pada waktu hakim memutuskan suatu perkara dengan memperhatikan terwujudnya kemanfaatan dan kemaslahatan bagi para pihak yang berperkara. Sedangkan dilihat dari sifatnya penelitian ini bersifat deskriptif analisis.

\section{HASIL DAN PEMBAHASAN}

Negara adalah suatu organisasi dalam suatu wilayah yang memiliki kekuasaan tertinggi yang sah dan ditaati oleh rakyatnya. Kekuasaan adalah kemampuan seseorang atau suatu kelompok untuk memengaruhi perilaku seseorang atau kelompok lain, sesuai dengan keinginan para pelaku. Keputusan adalah hasil dari membuat pilihan di antara beberapa 
alternatif. Kebijakan adalah suatu kumpulan keputusan yang diambil oleh seorang pelaku atau kelompok politik, dalam usaha memilih tujuan dan cara untuk mencapai tujuan itu. ${ }^{7}$

Menurut R. M. Maclver, Negara merupakan perkumpulan mendasar untuk membangun dan menyelenggarakan tatanan sosial, dan untuk tujuan ini, institusi pusat dibantu dengan adanya penyatuan kekuasaan komunitas. Menurut H. J. W. Hetherington, Negara adalah institusi atau seperangkat institusi yang menyatukan penduduknya dalam suatu wilayah teritorial yang ditandai secara jelas di bawah otoritas tunggal untuk menjamin tercapainya tujuan dasar dan kondisi kehidupan bersama. Sementara itu, menurut Woodrow Wilson, Negara adalah orang-orang yang diatur menurut hukum dalam suatu batas wilayah teritorial tertentu. ${ }^{8}$

Menurut Prof. Bernard Lewis, ada tiga penjelasan mengenai pengertian Islam:

1. Islam adalah wahyu dan teladan Nabi Muhammad SAW, yang dikodifikasikan menjadi al-qur'an dan hadist. Kedua sumber ajaran ini tidak pernah berubah. Yang berubah adalah penafsiran terhadapnya.

2. Islam yang diceritakan dalam ilmu kalam (terutama ilmu tauhid, aqaid, dan usuluddin), ilmu fiqih, dan tasawuf.

3. Islam historis, yaitu islam yang diwujudkan dalam peradaban dan kebudayaan yang dikembangkan oleh para penganutnya dalam arti luas, termasuk peradaban dan kebudayaan yang diwarisi oleh Islam walaupun bukan karya kaum muslimin.

\section{POLITIK DAN KEADILAN DI NEGARA DEMOKRASI}

Demokrasi dapat dilihat sebagai suatu Weltanschauung atau ideologi. Demokrasi juga dapat dilihat sebagai suatu sistem yang mengoperasionalkan ide-ide. Merumuskan suatu ideologi dalam garis-garis besar tidak terlalu sukar, akan tetapi mengoperasionalkannya, itulah yang paling sulit. ${ }^{10}$

Menurut teori keadilan Aristoteles menyatakan keadilan hukum mesti dipahami dalam pengertian kesamaan. Ia membagi kesamaan Numerik dan kesamaan Proporsional. Kesamaan numerik melahirkan prinsip : "semua orang sederajat di depan hukum”. Sedangkan kesamaan proporsional melahirkan prinsip : "memberi tiap orang apa yang menjadi

\footnotetext{
${ }^{7}$ Miriam Budiardjo, Dasar-Dasar Ilmu Politik, Gramedia Pustaka Utama, Jakarta: 2009, Hal 17-20

${ }^{8}$ C.F. Strong, Konstitusi-Konstitusi Politik Modern Study Perbandingan tentang Sejarah dan Bentuk, Nusa Media, Bandung: 2010, Hal. 6-7

${ }^{9}$ Abdul Azis Thaba, Islam dan Negara dalam Politik Orde Baru, Gema Insani Press, Jakarta: 1996, Hal. 38

${ }^{10}$ Miriam Budiardjo, Demokrasi di Indonesia, Demokrasi Parlementer dan Demokrasi Pancasila, PT SUN, Jakarta: 2000, Hal. 291
} 
haknya". ${ }^{11}$ Selain itu, Aristoteles juga memaknai keadilan yaitu memberikan barang dan penghormatan pada masing-masing anggota sesuai posisinya dalam masyarakat serta perlakuan sama di depan hukum (keadilan distributif) dan penghukuman terhadap orang yang berperilaku salah dan jahat, dan hukum harus diimplementasikan sama di muka pengadilan (keadilan remedial/correctif) ${ }^{12}$.

Berikutnya mengenai pengertian politik. Secara etimologis, istilah politik hukum merupakan terjemahan bahasa Indonesia dari istilah hukum Belanda rechtspolitiek, yang merupakan bentukan dari dua kata recht dan politiek. Recht berarti hukum, adapun dalam kamus bahasa Belanda yang ditulis oleh Van der Tas, kata politiek ${ }^{13}$ mengandung arti beleid. Kata beleid sendiri dalam bahasa Indonesia berarti kebijakan (policy). Dari penjelasan itu bisa dikatakan bahwa politik hukum secara singkat berarti kebijakan hukum.

\section{POLITIK DAN KEADILAN DI NEGARA ISLAM}

Sementara keadilan dalam konsep Islam adalah sistesis yang harmonis antara hukum dan moralitas. Keadilan yang terangkum dalam Al-Qur'an yakni “adl” yang artinya : sama atau tidak berat sebelah atau tidak memihak, berpihak kepada kebenaran, sepatutnya atau tidak sewenang-wenang. Al-Qur'an menetapkan bahwa salah satu sendi kehidupan bermasyarakat adalah keadilan. Tidak lebih dan tidak kurang. Berbuat baik melebihi keadilan seperti memaafkan yang bersalah atau memberi bantuan kepada yang malas akan dapat menggoyahkan sendi-sendi kehidupan bermasyarakat. Memang Al-Qur'an memerintahkan perbuatan adil dan kebaikan (Q.S An-Nahl:16), karena Ihsan (kebajikan) dinilai sebagai sesuatu yang melebihi keadilan. Namun dalam kehidupan bermasyarakat, keadilan lebih utama daripada kedermawanan atau ihsan. ${ }^{14}$

Sebagaimana dengan tepat orang dahulu mengatakan, keadilan adalah asas pemerintahan. Semua agama dan syari'at Illahi serta Undang-Undang duniawi berperan demikian. Akan tetapi keadilan dalam Islam bersifat mutlak lagi menyeluruh. Oleh sebab itu,

${ }^{11}$ Satjipto Rahardjo, Teori Hukum, Genta Publishing, Yogyakarta: 2010, Hal. 45

${ }^{12}$ Rohidin, Materi Kuliah Filsafat Hukum Islam, Di sampaikan pada Perkuliahan Filsafat Hukum Islam Pascasarjana Hukum UII, Tanggal 15 Januari 2011

${ }^{13}$ Istilah Politik, politiek dalam bahasa Belanda atau politics dalam bahasa Inggris berasal dari Bahas Yunani polis, berarti kota dan dibatasi pada kajian tentang negara. Dalam kepustakaan ilmu politik ternyata ada bermacam-macam definisi mengenai politik. Pada umumnya dapat dikatakan bahwa politik adalah bermacammacam kegiatan dalam suatu sistem politik (atau negara) yang menyangkut proses menentukan tujuan-tujuan dari sistem itu dan melaksanakan tujuan-tujuan itu. Abdul Rashid Moten, Ilmu Politik Islam (Political Science: An Islamic Perspective), diterjemahkan oleh Munir A. Mu'in dan Widyawati, Cet. I, (Bandung: Pustaka, 2001), Hal. 20; Miriam Budiarjo, Dasar-dasar Ilmu Politik, Cet. 17, (Jakarta: Gramedia, 1996), Hal. 8; M. Hamdan, Politik Hukum Pidana, Cet. I, (Jakarta: Raja Grafindo Persada, 1997), Hal. 2. Dalam Imam Syaukani dan Ahsin Thohari, op. cit., Hal. 19-21

${ }^{14}$ Ibid. 
Islam mewajibkan penerapannya terhadap kaum muslimin maupun non-muslim, teman ataupun lawan. Keadilan yang ditegakkan oleh sistem pemerintahan Islam dan dipandang sebagai salah satu dasarnya yang kuat adalah keadilan yang utama bagi semua orang, walaupun berbeda bangsa dan agama. Ia merupakan keadilan yang tidak terpengaruh oleh hubungan kerabat, kebesaran dan kekuasaan. Sebaliknya juga tidak boleh terpengaruh oleh rasa benci atau permusuhan atau faktor apapun, selain yang tersebut di atas. ${ }^{15}$

Oleh sebab itu, Allah menyuruh berbuat adil dan melarang berbuat sebaliknya, yaitu dhalim, sebagaimana terdapat dalam banyak ayat Al-Qur'an juga dengan keras diharamkan berbuat dhalim dan diancam dengan siksaan yang berat. Begitu pula banyak hadist Rasulullah dan praktek serta perilaku beliau sepanjang hidupnya yang memerintahkan keadilan. Islam bukan semata-mata slogan dan prinsip saja, tetapi juga agama, amal dan praktek dari prinsipprinsip yang telah ditetapkannya. Oleh karena itu, keadilan merupakan salah satu prinsip pemerintahan dan sendinya yang kokoh pada masa khulafaur-rasyidin dan para khalifah serta gubernur yang mengikuti jejak mereka. ${ }^{16}$

Islam mengajarkan tentang bagaimana seharusnya masyarakat itu diatur dan dikelola. Oleh sebab itu Islam sarat dengan tuntunan politik. Prinsip halal-haram dalam hubungan antara manusia, masalah hukum perdata-pidana yang dituntunkannya, masalah budaya yang harus dikembangkan manusia, masalah kualitas manusia yang layak dipilih sebagai pemimpin masyarakat/bangsa/negara, masalah perilaku ekonomi yang harus dianut, dan semacamnya membuat Islam tidak bisa terlepas dari dimensi politik kehidupan sosial manusia. Kekuasaan yang melaksanakan hukum dan aturan, juga bias disebut dengan aktifitas kepemimpinan yang telah diwajibkan oleh syara' atas kaum muslimin. Aktifitas kepemimpinan ini merupakan kekuasaan yang dipergunakan untuk menjaga terjadinya tindak kedzaliman serta memutuskan masalah-masalah yang dipersengketakan. ${ }^{17}$ Kondisi politik internal dan eksternal sangat mempengaruhi peranan strategis umat dalam pembentukan insitusi politik yang lebih demokratis. ${ }^{18}$

Inilah yang membedakan Islam dengan ajaran agama lain yang umumnya hanya memberi tuntunan untuk nilai spiritual, ritual, dan beberapa prinsip pokok moral belaka. Andaikata Islam juga hanya memberi tuntunan tentang aspek akidah (spiritual), ibadah (ritual), dan akhlak (prinsip umum moral) saja maka Islam tidak beda dengan agama lain, dan

\footnotetext{
${ }^{15}$ Yusuf Musa, Nidhamul Hukmi fil Islam, Kairo-Mesir: 1963 diterjemhkan oleh Thalib, Politik dan Negara dalam Islam, Al-Ikhlas, Surabaya: 1963, Hal. 185

${ }^{16}$ Ibid, Hal. 185-187

${ }^{17}$ Taqiyuddin An-Nabhani, Sistem Pemerintahan Islam, Al Izzah, Jatim: 1997, Hal. 11

${ }^{18}$ Kunto Wijoyo, Identitas Politik Umat Islam, Mizan, Bandung: 1997, Hal. 107
} 
tidak layak terlibat dalam urusan politik. Nyatanya isi Al-Qur'an 90\% sarat dengan masalah sosial, sehingga Islam memang memiliki dimensi politik dalam ajarannya. Umat Islam yang sadar tentu tidak boleh lari dari urusan politik di negerinya. Umat Islam yang sadar tidak boleh dikecoh orang untuk hanya ber-Islam dalam hal berfilsafat dan ritual belaka. ${ }^{19}$

\section{PERBEDAAN ANTARA NEGARA ISLAM DAN DEMOKRASI ${ }^{20}$}

Agama dan Negara adalah dua satuan sejarah yang berbeda hakikatnya. Agama adalah kabar gembira dan peringatan (basyiran wa nadzira, baca QS. Al-Baqarah (2) : 119), sedangkan negara adalah kekuatan pemaksa (coercion). Agama punya khatib, juru dakwah, dan ulama, sedangkan Negara punya birokrasi, pengadilan, dan tentara. Agama dapat mempengaruhi jalannya sejarah melalui kesadaran bersama (collective conscience), negara mempengaruhi sejarah dengan keputusan, kekuasaan, dan perang. Agama adalah kekuatan dari dalam dan Negara adalah kekuatan dari luar. ${ }^{21}$

Dr. Dhiyauddin ar Rais mengatakan, Ada beberapa persamaan yang mempertemukan Islam dan demokrasi. Namun, perbedaannya lebih banyak. Persamaannya menyangkut pemikiran sistem politik tentang hubungan antara umat dan penguasa serta tanggung jawab pemerintahan. Akhirnya, ar Rais sampai pada kesimpulan bahwa antara Islam dan demokrasi tidak hanya memiliki persamaan di bidang politik. Lebih dari itu, unsur-unsur yang terkandung dalam demokrasi dan keistimewaannya pun sudah terkandung di dalam Islam. Dalam menerangkan hal itu, dia mengatakan, Jika yang dimaksud dengan demokrasi seperti definisi Abraham Lincoln: dari rakyat dan untuk rakyat pengertian itu pun ada di dalam sistem negara Islam dengan pengecualian bahwa rakyat harus memahami Islam secara komprehensif. Jika maksud demokrasi adalah adanya dasar-dasar politik atau sosial tertentu (misalnya, asas persamaan di hadapan undang-undang, kebebasan berpikir dan berkeyakinan, realisasi keadilan sosial, atau memberikan jaminan hak-hak tertentu, seperti hak hidup dan bebas mendapat pekerjaan). Semua hak tersebut dijamin dalam Islam.

Jika demokrasi diartikan sebagai sistem yang diikuti asas pemisahan kekuasaan, itu pun sudah ada di dalam Islam. Kekuasaan legislatif sebagai sistem terpenting dalam sistem demokrasi diberikan penuh kepada rakyat sebagai satu kesatuan dan terpisah dari kekuasaan Imam atau Presiden. Pembuatan Undang-Undang atau hukum didasarkan pada alQuran dan Hadist, ijma, atau ijtihad. Dengan demikian, pembuatan UU terpisah dari Imam, bahkan

\footnotetext{
${ }^{19}$ Fuad Amsyari, Islam Kaaffah Tantangan Sosial dan Aplikasinya di Indonesia, Gema Insani Press, Jakarta: 1995, Hal. 226

${ }^{20} \mathrm{http}: / /$ dhekasasmita.wordpress.com/2010/03/page/2/

${ }^{21}$ Kunto Wijoyo, op., cit, Hal. 191-192
} 
kedudukannya lebih tinggi dari Imam. Adapun Imam harus menaatinya dan terikat UU. Pada hakikatnya, Imamah (kepemimpinan) ada di kekuasaan eksekutif yang memiliki kewenangan independen karena pengambilan keputusan tidak boleh didasarkan pada pendapat atau keputusan penguasa atau presiden, jelainkan berdasarkan pada hukum-hukum syariat atau perintah Allah Swt.

Menurut Dhiyauddin ar Rais, ada tiga hal yang membedakan Islam dan demokrasi :

1. Dalam demokrasi yang sudah populer di Barat, definisi bangsa atau umat dibatasi batas wilayah, iklim, daerah, suku-bangsa, bahasa dan adat-adat yang mengkristal. Dengan kata lain, demokrasi selalu diiringi pemikiran nasionalisme atau rasialisme yang digiring tendensi fanatisme. Adapun menurut Islam, umat tidak terikat batas wilayah atau batasan lainnya. Ikatan yang hakiki di dalam Islam adalah ikatan akidah, pemikiran dan perasaan. Siapa pun yang mengikuti Islam, ia masuk salah satu negara Islam terlepas dari jenis, warna kulit, negara, bahasa atau batasan lain. Dengan demikian, pandangan Islam sangat manusiawi dan bersifat internasional.

2. Tujuan-tujuan demokrasi modern Barat atau demokrasi yang ada pada tiap masa adalah tujuan-tujuan yang bersifat duniawi dan material. Jadi, demokrasi ditujukan hanya untuk kesejahteraan umat (rakyat) atau bangsa dengan upaya pemenuhan kebutuhan dunia yang ditempuh melalui pembangunan, peningkatan kekayaan atau gaji. Adapun demokrasi Islam selain mencakup pemenuhan kebutuhan duniawi (materi) mempunyai tujuan spiritual yang lebih utama dan fundamental.

3. kedaulatan umat (rakyat) menurut demokrasi Barat adalah sebuah kemutlakan. Jadi, rakyat adalah pemegang kekuasaan tertinggi tanpa peduli kebodohan, kezaliman atau kemaksiatannya. Namun dalam Islam, kedaulatan rakyat tidak mutlak, melainkan terikat dengan ketentuan-ketentuan syariat sehingga rakyat tidak dapat bertindak melebihi batasan-batasan syariat, alQuran dan asSunnah tanpa mendapat sanksi. Menurut Islam, kekuasaan tertinggi bukan di tangan penguasa karena Islam tidak sama dengan paham otokrasi. Kekuasaan bukan pula di tangan tokoh-tokoh agamanya karena Islam tidak sama dengan teokrasi. Begitupun bukan di tangan UU karena Islam tidak sama dengan nomokrasi atau di tangan umat karena Islam bukan demokrasi dalam pengertian yang sempit. Jawabannya, kekuasaan tertinggi dalam Islam sangat nyata sebagai perpaduan dua 
hal, yaitu umat dan undang-undang atau syariat Islam. Jadi, syariat pemegang kekuasaan penuh dalam negara Islam.

Dr. Dhiyauddin ar Rasi menambahkan, jika harus memakai istilah demokrasi tanpa mengabaikan perbedaan substansialnya sistem itu dapat disebut sebagai demokrasi yang manusiawi, menyeluruh (internasional), religius, etis, spiritual, sekaligus material. Boleh pula disebut sebagai demokrasi Islam atau menurut al Maududy demokrasi teokrasi. Demokrasi seperti itulah yang dipahami aktivis Islam termasuk Ikhwanul Muslimun saat terjun di dalam kehidupan politik dan bernegara di negara demokrasi.

Ustadz Mamun al Hudhaibi hafizhahullah pernah ditanya pandangan Ikhwan tentang demokrasi dan kebebasan individu. Katanya, Jika demokrasi berarti rakyat memilih orang yang akan memimpin mereka, Ikhwan menerima demokrasi. Namun, jika demokrasi berarti rakyat dapat mengubah hukum-hukum Allah Swt dan mengikuti kehendak mereka, Ikhwan menolak demokrasi. Ikhwan hanya mau terlibat dalam sistem yang memungkinkan syariat Islam diberlakukan dan kemungkaran dihapuskan. Menolong, meskipun sedikit, masih lebih baik daripada tidak menolong. Mengenai kebebasan individu, Ikhwan menerima kebebasan individu dalam batas-batas yang dibolehkan Islam. Namun, kebebasan individu yang menjadikan muslimah memakai pakaian pendek, minim dan atau seperti pria adalah haram dan Ikhwan tidak akan toleran dengan hal itu.

\section{KESIMPULAN}

Negara Demokrasi maupun Negara Islam sama-sama menggunakan politik. Karena, dalam permaknaan yang sederhana politik adalah strategi, teknik mengatur. Politik juga sudah digunakan dalam islam sejak zaman Nabi Muhammad SAW. Beliau selaku orang yang menyebarkan agama islam dan dalam penyebaran agama tersebut menggunakan strategi yang sama halnya dengan politik.

Keadilan adalah suatu hal yang selalu menjadi dasar cita-cita setiap Negara, apapun bentuk Negara tersebut tentu mempunyai visi dan misi yang tak luput dari keinginan pencapaian keadilan. Begitu juga dengan Negara Demokrasi maupun Negara Islam. Selain persamaan terhadap visi dan misi keadilan tersebut, persamaan lain yang tampak adalah menyangkut pemikiran sistem politik tentang hubungan antara umat dan penguasa serta tanggung jawab pemerintahan.

Mengenai perbedaan diantara Negara demokrasi dengan Negara islam adalah dalam demokrasi yang sudah populer di Barat, definisi bangsa atau umat dibatasi batas wilayah, 
iklim, daerah, suku-bangsa, bahasa dan adat-adat yang mengkristal sementara menurut Islam, umat tidak terikat batas wilayah atau batasan lainnya. Dan tujuan-tujuan demokrasi modern Barat atau demokrasi yang ada pada tiap masa adalah tujuan-tujuan yang bersifat duniawi dan material adapun demokrasi Islam selain mencakup pemenuhan kebutuhan duniawi (materi) mempunyai tujuan spiritual yang lebih utama dan fundamental. Serta kedaulatan umat (rakyat) menurut demokrasi Barat adalah sebuah kemutlakan. Namun dalam Islam, kedaulatan rakyat tidak mutlak, melainkan terikat dengan ketentuan-ketentuan syariat sehingga rakyat tidak dapat bertindak melebihi batasan-batasan syariat, Al-Quran dan As Sunnah tanpa mendapat sanksi.

\section{DAFTAR PUSTAKA}

Amsyari, Fuad, Islam Kaaffah Tantangan Sosial dan Aplikasinya di Indonesia, Gema Insani Press, Jakarta: 1995

An-Nabhani, Taqiyuddin, Sistem Pemerintahan Islam, Al Izzah, Jatim: 1997

Budiardjo, Miriam, Dasar-Dasar Ilmu Politik, Gramedia Pustaka Utama, Jakarta: 2009

Budiardjo, Miriam, Demokrasi di Indonesia, Demokrasi Parlementer dan Demokrasi Pancasila, PT SUN, Jakarta: 2000

Kelsen, Hans, Pengantar Teori Hukum, Nusa Media, Bandung, 2009

Mahfud, Konstitusi dan Hukum dalam Kontroversi Isu, Rajawali Pers, Jakarta: 2009

Mahfud, Politik Hukum di Indonesia, Rajawali Pers, Jakarta: 2009

Rahardjo, Satjipto, Ilmu Hukum, Citra Aditya Bakti, Bandung: 2000

Rahardjo, Satjipto, Teori Hukum, Genta Publishing, Yogyakarta: 2010

Strong, Konstitusi-Konstitusi Politik Modern Study Perbandingan tentang Sejarah dan Bentuk, Nusa Media, Bandung: 2010

Syaukani, Imam dan Ahsin Thohari, Dasar-Dasar Politik Hukum, Raja Grafindo Persada, Jakarta: 2008

Thaba, Abdul Azis, Islam dan Negara dalam Politik Orde Baru, Gema Insani Press, Jakarta: 1996 
Wijoyo, Kunto, Identitas Politik Umat Islam, Mizan, Bandung: 1997

Musa, Yusuf, Nidhamul Hukmi fil Islam, Kairo-Mesir: 1963 diterjemhkan oleh Thalib, Politik dan Negara dalam Islam, Al-Ikhlas, Surabaya: 1963

Rohidin, Materi Kuliah Filsafat Hukum Islam, Di sampaikan pada Perkuliahan Filsafat Hukum Islam Pascasarjana Hukum UII, Tanggal 15 Januari 2011

http://dhekasasmita.wordpress.com/2010/03/page/2/ 